\title{
ANALISIS PENGARUH KINERJA PERBANKAN TERHADAP DANA PIHAK KETIGA BANK PERSERO
}

\author{
Iqbal Firdausi \\ STIE Indonesia, Banjarmasin - Indonesia
}

\begin{abstract}
This study aimed to analyze the effect of the performance of banks consisting of CAR, ROA, ROA, LDR simultaneously and partially on the Third Party Funds and analyze between the performance of banks consisting of CAR, ROA, ROA, LDR the dominant influence on the Third party Fund. Forms of this research is descriptive explanatory nature of causality through hypothesis testing. The number of samples in the study of 4 Bank Limited for 11 years i.e. from 2004 to 2014 year. The analysis technique used multiple regression analysis. The analysis showed that the performance of banks consisting of CAR, ROA, ROA, LDR simultaneously affect the Third Party Funds. Performance of banks consisting of CAR, ROA, ROA, LDR partially affect the Third Party Funds. ROA dominant influence on Third Party Funds.
\end{abstract}

Keywords: CAR, ROA, ROA, LDR, Third Party Funds

\section{PENDAHULUAN}

Dunia perbankan merupakan salah satu institusi yang sangat berperan dalam bidang perekonomian suatu Negara, khususnya di bidang pembiayaan perekonomian. Berdasarkan UU No. 10 tahun 1998 tentang perbankan, bank adalah badan usaha yang menghimpun dana dari masyarakat dalam bentuk simpanan dan menyalurkannya kepada masyarakat dalam bentuk kredit dan bentuk-bentuk lainnya dalam rangka meningkatkan taraf hidup rakyat banyak. Bank merupakan bagian dari lembaga keuangan yang memiliki fungsi intermediasi yaitu menghimpun dana dari masyarakat yang kelebihan dana dan menyalurkan dana yang dihimpunnya kepada masyarakat yang kekurangan dana. Melalui sebuah bank dapat dihimpun dana dari masyarakat dalam berbagai bentuk simpanan selanjutnya dari dana yang telah terhimpun tersebut, oleh bank disalurkan kembali dalam bentuk pemberian kredit kepada sektor bisnis atau pihak lain yang membutuhkan. Semakin berkembang kehidupan masyarakat dan transaksitransaksi perekonomian suatu negara, maka akan membutuhkan pula peningkatan peran sektor perbankan melalui pengembangan produk-produkjasanya. Dana-dana yang dihimpun dari masyarakat

Korespondensi dengan Penulis:

Iqbal Firdausi. HP: +6281237911111

e-mail: iqbal_firdausi@yahoo.co.id 


\section{Jurnal Keuangan dan Perbankan | PERBANKAN}

Vol. 20, No.3, September 2016: 487- 495

(Dana Pihak Ketiga) merupakan sumber dana terbesar yang paling diandalkan oleh bank (Dendawijaya, 2009).

Kinerja perbankan dapat dinilai dari beberapa indikator. Salah satu indikator utama yang dijadikan sebagai dasar penilaian adalah laporan keuangan bank yang bersangkutan. Berdasarkan laporan keuangan akan dapat dihitung sejumlah rasio keuangan yang lazim dijadikan sebagai dasar penilaian tingkat kesehatan bank. Hasil analisis laporan keuangan akan membantu menginterpretasikan berbagai hubungan kunci serta kecenderungan yang dapat memberikan dasar pertimbangan mengenai potensi keberhasilan perusahaan dimasa mendatang (Sunyoto dan Sam'ani, 2014)

Analisis laporan keuangan dapat digunakan untuk meneliti atau menilai kinerja keuangan, kinerja keuangan yang dimaksud meliputi aspek BOPO (Biaya operasional terhadap pendapatan operasional), CAR (Capital Adequacy Ratio), Return on Asset (ROA) dan Loan to Deposit Ratio (LDR). Keempat aspek tersebut masing-masing capital, asset, earning dan liquidity dinilai dengan menggunakan rasio keuangan, hal ini menunjukkan bahwa rasio keuangan bermanfaat dalam menilai kondisi keuangan suatu perusahaan.

BOPO termasuk rasio rentabilitas (earnings). Keberhasilan bank didasarkan pada penilaian kuantitatif terhadap rentabilitas bank dapat diukur dengan menggunakan rasio biaya operasional terhadap pendapatan operasional. Menurut Dendawijaya (2009) rasio biaya operasional digunakan untuk mengukur tingkat efisiensi dan kemampuan bank dalam melakukan kegiatan operasinya. Rasio Biaya Operasional terhadap Pendapatan Operasional (BOPO) sering disebut rasio efisiensi digunakan untuk mengukur kemampuan manajemen bank dalam mengendalikan biaya operasional terhadap pendapatan operasional. Semakin kecil rasio ini berarti semakin efisien biaya operasional yang dikeluarkan bank yang bersangkutan.
Return on Asset (ROA) memfokuskan pada kemampuan perusahaan untuk memperoleh earning dalam operasi. ROA merupakan rasio antara laba sesudah pajak terhadap total assets. Semakin besar ROA menunjukkan kinerja perusahaan semakin baik, karena tingkat pengembalian (return) semakin besar. ROA juga merupakan perkalian antara faktor net income margin dengan perputaran aktiva. Net Income Margin menunjukkan kemampuan memperoleh laba dari setiap penjualan yang diciptakan oleh perusahaan, sedangkan perputaran aktiva menunjukkan seberapa jauh perusahaan mampu menciptakan penjualan dari aktiva yang dimiliki. Apabila salah satu dari faktor tersebut meningkat (atau keduanya), maka ROA juga akan meningkat. Alasan dipilihnya industri perbankan karena kegiatan bank sangat diperlukan bagi lancarnya kegiatan perekonomian di sektor riil. Sektor riil tidak akan dapat berkinerja dengan baik apabila sektor moneter tidak bekerja dengan baik.

LDR adalah rasio antara seluruh jumlah kredit yang diberikan bank dengan dana yang diterima bank. LDR menggambarkan seberapa jauh kemampuan bank dalam membayar kembali penarikan dana yang dilakukan deposan dengan mengandalkan kredit yang diberikan sebagai sumber likuiditasnya. Semakin tinggi rasio LDR memberikan indikasi semakin rendahnya kemampuan likuiditas bank yang bersangkutan. Hal ini disebabkan karena jumlah dana yang diperlukan untuk membiayai kredit menjadi semakin besar. Ukuran untuk menghitug likuiditas bank adalah Loan to Deposit Ratio (LDR), yaitu seberapa besar dana bank dilepaskan ke perkreditan. Ketentuan Bank Indonesia tentang Loan to Deposit Ratio (LDR) yaitu antara ratio $80 \%$ hingga $110 \%$ (Lukitasari dan Kartika, 2015). Semakin tinggi LDR maka laba bank akan semakin meningkat (dengan asumsi bank tersebut mampu menyalurkan kreditnya dengan efektif sehingga dengan meningkatnya laba bank tersebut maka kinerja bank juga semakin meningkat).

Penelitian ini bertujuan untuk menganalisis pengaruh kinerja perbankan yang terdiri dari CAR, 
BOPO, ROA, LDR secara simultan maupun secara parsial terhadap Dana Pihak Ketiga dan menganalisis di antara kinerja perbankan yang terdiri dari CAR, BOPO, ROA, LDR yang berpengaruh dominan terhadap Dana Pihak Ketiga.

\section{Kinerja Perbankan}

Kinerja bank sangat penting sebagai alat untuk mengevaluasi operasi bank dan menentukan rencana manajemen dan analisis strategis. Bank mempunyai peran dalam pertumbuhan ekonomi. Jadi jika kinerja bank baik, keseluruhan perekonomian juga akan baik. Kinerja perbankan merupakan gambaran prestasi yang dicapai dalam operasional bank, baik menyangkut aspek keuangan, pemasaran, penghimpunan, dan penyaluran dana, teknologi maupun sumber daya manusia (Rose, 2002: 138). Kinerja keuangan bank merupakan gambaran kondisi keuangan bank pada suatu periode tertentu baik menyangkut aspek penghimpunan dana maupun penyaluran dana yang biasanya diukur dengan indikator kecukupan modal, likuiditas, dan profitabilitas bank (Jumingan, 2011).

Kinerja bank mempunyai dua indikator dan dua dimensi penting. Indikator kinerja bank adalah indikator kualitas dan kuantitas. Dimensi kinerja bank adalah dimensi profitabilitas dan dimensi risiko. Ukuran profitabilitas yang bisa dipakai sebagai proxy adalah ROA (return on assets) dan ROE (return on equity), sedangkan ukuran risiko yang bisa dipakai sebagai proxy adalah LDR (loans to deposit ratio) dan CAR (capital adequacy ratio) (Rose, 2002:138).

\section{Capital Adequacy Ratio (CAR)}

Capital Adequacy Ratio (CAR) adalah rasio kecukupan modal yang berfungsi menampung risiko kerugian yang kemungkinan dihadapi oleh bank. Semakin tinggi CAR maka semakin baik kemampuan bank tersebut untuk menanggung risiko dari setiap kredit/aktiva produktif yang berisiko. Jika nilai CAR tinggi maka bank tersebut mampu membiayai kegiatan operasional dan memberikan kontribusi yang cukup besar bagi profitabilitas. Capital Adequacy Ratio menurut Dendawijaya (2009:122) adalah "Rasio yang memperlihatkan seberapa jauh seluruh aktiva bank yang mengandung risiko (kredit, penyertaan, surat berharga, tagihan pada bank lain) ikut dibiayai dari dana modal sendiri bank di samping memperoleh dana-dana dari sumber-sumber di luar bank, seperti dana dari masyarakat, pinjaman, dan lain-lain. CAR merupakan indikator terhadap kemampuan bank untuk menutupi penurunan aktivanya sebagai akibat dari kerugian-kerugian bank yang disebabkan oleh aktiva yang berisiko.

\section{Biaya Operasional terhadap Pendapatan Operasional (BOPO)}

Rasio Biaya Operasional terhadap Pendapatan Operasional (BOPO) menurut kamus keuangan adalah kelompok rasio yang mengukur efisiensi dan efektivitas operasional suatu perusahaan dengan jalur membandingkan satu terhadap lainnya. Berbagai angka pendapatan dan pengeluaran dari laporan rugi laba dan terhadap angka-angka dalam neraca. Rasio biaya operasional adalah perbandingan antara biaya operasional dan pendapatan operasional. Rasio biaya operasional digunakan untuk mengukur tingkat efisiensi dan kemampuan bank dalam melakukan kegiatan operasi (Wijaya, 2009:120). Semakin rendah BOPO berarti semakin efisien bank tersebut dalam mengendalikan biaya operasionalnya, dengan adanya efisiensi biaya maka keuntungan yang diperoleh bank akan semakin besar.

\section{Return On Asset (ROA)}

Return On Asset merupakan rasio antar laba bersih yang berbanding terbalik dengan keseluruhan aktiva untuk menghasilkan laba. Rasio ini me- 


\section{Jurnal Keuangan dan Perbankan | PERBANKAN}

Vol. 20, No.3, September 2016: 487- 495

nunjukkan berapa besar laba bersih yang diperoleh perusahaan diukur dari nilai aktivanya. Analisis Return On assets atau sering diterjemahkan dalam bahasa Indonesia sebagai rentabilitas ekonomi mengukur perkembangan perusahaan menghasilkan laba pada masa lalu. Analisis ini kemudian diproyeksikan ke masa mendatang untuk melihat kemampuan perusahaan menghasilkan laba pada masa-masa mendatang. Menurut Simamora (2006:52) Return on Asset yaitu “Rasio imbalan aktiva (ROA) merupakan suatu ukuran keseluruhan profitabilitas perusahaan."

\section{Loan Deposit Ratio (LDR)}

Menurut Mulyono (2007:101), rasio LDR merupakan rasio perbandingan antara jumlah dana yang disalurkan ke masyarakat (kredit) dengan jumlah dana masyarakat dan modal sendiri yang digunakan. Rasio ini menggambarkan kemampuan bank membayar kembali penarikan yang dilakukan nasabah deposan dengan mengandalkan kredit yang diberikan sebagai sumber likuiditasnya. Semakin tinggi rasio ini semakin rendah pula kemampuan likuiditas bank (Dendawijaya, 2009:118). Sebagian praktisi perbankan menyepakati bahwa batas aman dari LDR suatu bank adalah sekitar $85 \%$. Namun batas toleransi berkisar antara $85 \%$ $100 \%$ atau menurut Kasmir (2012:272), batas aman untuk LDR menurut peraturan pemerintah adalah maksimum $110 \%$.

\section{Dana Pihak Ketiga}

Dana pihak ketiga (simpanan) yang dijelaskan dalam UU Perbankan RI No. 10 tahun 1998 tentang perbankan adalah dana yang dipercayakan oleh masyarakat kepada bank berdasarkan perjanjian penyimpanan dana dalam bentuk giro, deposito, sertifikat deposito, tabungan, dan atau bentuk lainnya yang dipersamakan dengan itu. Menurut Kasmir (2012:64), dana pihak ketiga adalah dana yang berasal dari masyarakat luas yang merupakan sumber dana terpenting bagi kegiatan operasional suatu bank dan merupakan ukuran keberhasilan bank jika mampu membiayai operasional dari sumber dana ini. Dana pihak ketiga menurut Suyatno (2007:38) yaitu simpanan pihak ketiga adalah berupa penyimpanan sejumlah uang di bank dalam bentuk Giro, Tabungan, Deposito, Rekening Koran. Dana pihak ketiga dibutuhkan suatu bank dalam menjalankan operasinya. Dendawijaya (2009) mendefinisikan dana pihak ketiga adalah dana berupa simpanan dari masyarakat. Ternyata merupakan sumber dana terbesar yang paling diandalkan oleh bank (bisa mencapai $80 \%-90 \%$ dari seluruh dana yang dikelola oleh bank).

\section{HIPOTESIS}

$\mathrm{H}_{1}$ : Kinerja perbankan yang terdiri dari CAR, BOPO, ROA dan LDR secara simultan berpengaruh terhadap dana pihak ketiga.

$\mathrm{H}_{2}$ : Kinerja perbankan yang terdiri dari CAR, BOPO, ROA dan LDR secara parsial berpengaruh terhadap dana pihak ketiga.

$\mathrm{H}_{3}$ : LDR berpengaruh dominan terhadap dana pihak ketiga.

\section{METODE}

Bentuk penelitian ini berupa penelitian deskriptif ekplanatori yang bersifat kausalitas melalui pengujian hipotesis untuk menganalisis pengaruh kinerja perbankan terhadap Dana Pihak Ketiga.

Kinerja perbankan merupakan kondisi keuangan bank pada tahun 2004 sampai dengan 2014 yang diamati dengan rasio per bulan dari bank persero data Bank Indonesia

1) CAR

CAR merupakan penilaian aspek permodalan lebih dimaksudkan untuk mengetahui bagaimana atau berapa modal bank tersebut telah memadai untuk menunjang usaha. 
$\mathrm{CAR}=\frac{\text { Modal Bank }}{\text { Total ATMR }} \times 100 \%$

2) $\mathrm{BOPO}$

Rasio BOPO sering disebut rasio efisiensi yang digunakan untuk mengukur kemampuan manajemen bank dalam mengendalikan biaya operasional terhadap pendapatan operasional. BOPO $=\frac{\text { Biaya Operasi }}{\text { Pendapatan Operasi }} \times 100 \%$

3) $\mathrm{ROA}$

Return On Assets, menunjukkan kemampuan perusahaan dalam menghasilkan laba dengan seluruh aktiva perusahaan.

ROA $=\frac{\text { Laba Bersih }}{\text { Total Aktiva }} \times 100 \%$

4) LDR

LDR untuk mengukur seberapa besar kemampuan bank tersebut mampu membayar utangutang dan membayar kembali kepada deposan serta dapat memenuhi permintaan kredit yang diajukannya tanpa terjadi penangguhan.

$\mathrm{LDR}=\frac{\text { Kredit }}{\text { Dana Pihak Ketiga }} \times 100 \%$

Dana pihak ketiga merupakan dana masyarakat dalam bentuk giro, deposito, dan tabungan yang dilaporkan Bank Indonesia dari tahun 2004 - 2014, yang diukur dalam rupiah.

Populasi penelitian ini adalah seluruh Bank Persero di Indonesia dimana pada tahun 2014 berjumlah 4 bank yang terdiri dari: PT. Bank Negara Indonesia 46 (Persero), Tbk; PT. Bank Mandiri (Persero), Tbk; PT. Bank Rakyat Indonesia (Persero), Tbk dan PT. Bank Tabungan Nasional (Persero). Adapun yang menjadi sampel penelitian adalah seluruh bank persero di Indonesia, dengan demikian metode penarikan sampel yang digunakan adalah metode sensus yaitu pengambilan sampel secara menyeluruh yaitu sebanyak 4 bank dengan periode penelitian selama 11 tahun dari 2004 sampai dengan tahun 2014. Data tersebut dikumpulkan secara runtut waktu (time series) yaitu data yang secara kronologis disusun menurut waktu pada suatu variabel tertentu dan secara kerat lintang (cross section), yaitu data yang dikumpulkan pada suatu titik waktu, yang disebut dengan polling data dengan combined model. Penelitian ini menggunakan 4 bank selama 11 tahun (series) yaitu tahun 2004 sampai dengan tahun 2014, dengan combined model data yang diperoleh sebanyak 132.

Teknik analisis yang digunakan yaitu analisis regresi berganda dengan menggunakan formulasi:

$\mathrm{Y}=\mathrm{a}+\mathrm{b}_{1} \mathrm{X}_{1}+\mathrm{b}_{2} \mathrm{X}_{2}+\mathrm{b}_{3} \mathrm{X}_{3}+\mathrm{b}_{4} \mathrm{X}_{4}+\mathrm{e}$

Keterangan:
$Y^{\prime}:$ Dana Pihak Ketiga
$\mathrm{a}:$ Konstansta
$\mathrm{X}_{1}:$ CAR
$\mathrm{X}_{2}:$ BOPO
$\mathrm{X}_{3}:$ ROA
$\mathrm{X}_{4}:$ LDR
$\varepsilon:$ error

\section{HASIL}

Persamaan garis regresi berdasarkan hasil analisis yang dilakukan dengan melihat ukuran variabel, digunakan unstandardized coefficients beta yang dijelaskan pada Tabel 1 berikut.

Berdasarkan Tabel 1 dapat diketahui bahwa pengaruh CAR terhadap Dana Pihak Ketiga adalah signifikan, dengan koefisien regresi 25348,482 dan standard error sebesar 5265,898 serta nilai t sebesar 4,814 dan nilai p sebesar 0,000. Artinya CAR berpengaruh signifikan terhadap Dana Pihak Ketiga, yang berarti peningkatan CAR akan diikuti dengan peningkatan Dana Pihak Ketiga.

Pengaruh BOPO terhadap Dana Pihak Ketiga adalah signifikan pada level $\alpha=5 \%$, dengan koefisien regresi $-1976,727$ dan standard error sebesar 


\section{Jurnal Keuangan dan Perbankan | PERBANKAN}

Vol. 20, No.3, September 2016: 487-495

730,477 serta nilai t sebesar $-2,706$ dan nilai $p$ sebesar 0,008. Artinya BOPO berpengaruh signifikan terhadap Dana Pihak Ketiga, yang berarti peningkatan $\mathrm{BOPO}$ akan diikuti dengan penurunan Dana Pihak Ketiga.

Pengaruh ROA terhadap Dana Pihak Ketiga adalah signifikan pada level $\alpha=5 \%$, dengan koefisien regresi 34780,775 dan standard error sebesar 17128,791 serta nilai $t$ sebesar 2,031 dan nilai $p$ sebesar 0,044. Artinya ROA berpengaruh signifikan terhadap Dana Pihak Ketiga, yang berarti peningkatan ROA akan diikuti dengan peningkatan Dana Pihak Ketiga.

Pengaruh LDR terhadap Dana Pihak Ketiga adalah signifikan pada level $\alpha=5 \%$, dengan koefisien regresi 20532,471 dan standard error sebesar 1390,018 serta nilai t sebesar 14,771 dan nilai p sebesar 0,000. Artinya LDR berpengaruh signifikan terhadap Dana Pihak Ketiga, yang berarti peningkatan LDR akan diikuti dengan peningkatan Dana Pihak Ketiga.

Dari hasil analisis regresi linier berganda, dapat diketahui bahwa nilai koefisien determinasi (adjusted $R$ square) sebesar 0,854. Angka ini menunjukkan bahwa variabel CAR, BOPO, ROA dan LDR dapat menjelaskan variasi atau mampu memberikan kontribusi terhadap variabel Dana Pihak Ketiga sebesar $85,4 \%$, sedangkan sisanya sebesar $14,6 \%$ disebabkan oleh variabel lain yang tidak dimasukkan dalam penelitian.
Berdasarkan hasil perhitungan diperoleh nilai F sebesar 192,825 dan nilai probabilitas lebih kecil dari $\alpha=0,05(0,000<0,05)$, yang berarti bahwa CAR, BOPO, ROA dan LDR secara simultan atau bersama-sama berpengaruh signifikan terhadap Dana Pihak Ketiga.

Berdasarkan Tabel 1 dapat diketahui bahwa nilai koefisien regresi terbesar yaitu ROA sebesar 34780,775, hal ini berarti ROA merupakan variabel yang berpengaruh dominan terhadap Dana Pihak Ketiga dibandingkan CAR, BOPO dan LDR.

\section{PEMBAHASAN}

Kinerja perbankan yang terdiri dari CAR, BOPO, ROA dan LDR secara simultan berpengaruh signifikan terhadap dana pihak ketiga, yang berarti semakin baik kinerja perbankan semakin banyak dana pihak ketiga yang berhasil dihimpun dari masyarakat. Kinerja perbankan tercermin dari laba operasional dan laba bersih per saham serta beberapa rasio keuangan yang menggambarkan kekuatan manajemen dalam mengelola perbankan. Kinerja perbankan yang ditunjukkan dalam laporan keuangan bermanfaat bagi para pengambil keputusan, terutama investor yang menanamkan dananya di bank. Analisis laporan keuangan dilakukan melalui perhitungan rasio-rasio keuangan, maka investor dapat melakukan prediksi return saham yang diinginkan sehingga dapat dibuat portofolio yang menguntungkan dari hasil investasinya.

Tabel 1 Hasil Analisis Regresi Linier Berganda

\begin{tabular}{|c|c|c|c|c|c|}
\hline Variabel & & $\begin{array}{c}\text { Koefisien } \\
\text { Regresi } \\
\end{array}$ & Standard error & Nilai $\mathbf{t}$ & Nilai $p$ \\
\hline CAR & & 25348,482 & 5265,898 & 4,814 & $0,000^{*}$ \\
\hline BOPO & & $-1976,727$ & 730,477 & $-2,706$ & $0,008^{*}$ \\
\hline ROA & & 34780,775 & 17128,791 & 2,031 & $0,044^{*}$ \\
\hline LDR & & 20532,471 & 1390,018 & 14,771 & $0,000^{*}$ \\
\hline $\mathrm{F}$ & : 192,825 & & & & \\
\hline Sig F & $: \quad 0,000$ & & & & \\
\hline$R$ square & $: \quad 0,859$ & & & & \\
\hline Adjusted R Square & $: \quad 0,854$ & & & & \\
\hline
\end{tabular}

*) secara statistik signifikan pada level $\alpha=5 \%$. 
Capital Adequacy Ratio (CAR) berpengaruh signifikan terhadap Dana Pihak Ketiga, hal ini menunjukkan bahwa tingginya CAR dapat menambah kepercayaan masyarakat terhadap bank, karena jaminan dana masyarakat semakin tinggi, sehingga semakin banyak dana pihak ketiga yang bisa dihimpun dari masyarakat. Seiring dengan bertambahnya modal bank dan bertambahnya kepercayaan masyarakat terhadap bank, maka bank dapat melakukan ekspansi kredit untuk meningkatkan pendapatan operasionalnya. Capital Adequacy Ratio (CAR) merupakan rasio permodalan yang menunjukkan kemampuan bank dalam menyediakan dana untuk keperluan pengembangan usaha dan menampung risiko kerugian dana yang diakibatkan oleh kegiatan operasi bank. Semakin tinggi CAR maka semakin besar pula sumber daya finansial yang dapat digunakan untuk keperluan pengembangan usaha dan mengantisipasi potensi kerugian yang diakibatkan oleh penyaluran kredit. CAR memang sangat penting bagi suatu bank karena menunjukkan kemampuan bank dalam mempertahankan modal yang mencukupi dan kemampuan manajemen dalam mengidentifikasi, mengukur, mengawasi, dan mengontrol risiko-risiko yang timbul yang dapat berpengaruh terhadap besarnya modal bank. Tetapi, semakin besar CAR maka dapat mengurangi kemampuan bank dalam melakukan ekspansi usaha karena semakin besarnya cadangan modal yang digunakan untuk menutupi risiko kerugian. Terhambatnya ekspansi usaha akibat tinggi CAR yang pada akhirnya akan mempengaruhi kinerja keuangan bank. Tingkat CAR tinggi mencerminkan bank yang terlalu berhatihati dalam menjalankan operasional. Hal ini menyebabkan bank cenderung mengabaikan kesempatan kegiatan yang berpotensi menghasilkan keuntungan. Ketentuan yang mewajibkan nilai CAR di atas $8 \%$ memberikan keuntungan berupa rasa aman dan terminimalisirnya risiko kebangkrutan pada bank. Benefit tersebut dapat mempengaruhi profitabilitas bank serta meningkatkan kepercayaan nasabah. Namun, dengan adanya ketentuan tersebut, strategi maupun langkah bank menjadi terbatasi akibat kewajiban memenuhi tingkat modal pada nilai tertentu. Hal ini berpengaruh pada pendapatan yang mungkin didapat oleh bank dengan memanfaatkan modal, tidak untuk dijaga pada tingkat tertentu demi memenuhi peraturan BI, melainkan untuk diutilisasi pada strategi dengan return lebih tinggi. Bank dengan nilai CAR yang rendah akan memiliki biaya yang tinggi dari kemungkinan terjadinya kebangkrutan. Kenaikan CAR dapat menurunkan kemungkinan tersebut serta meningkatkan ROA melalui penurunan biaya asuransi yang harus dikeluarkan bank atas hutang yang tidak diasuransikan.

BOPO berpengaruh negatif terhadap Dana Pihak Ketiga, hal ini menunjukkan bahwa semakin efisien bank dalam mengelola perbankan dapat meningkatkan dana pihak ketiga. BOPO diukur secara kuantitatif dengan mengunakan rasio efisiensi. Melalui rasio BOPO diukur apakah manajemen bank telah mengunakan semua faktor produksinya dengan efektif dan efisien, sehingga dapat meningkatkan kepercayaan masyarakat pada bank.

ROA berpengaruh signifikan terhadap Dana Pihak Ketiga, dan merupakan variabel yang berpengaruh dominan terhadap Dana Pihak Ketiga. Hal ini menunjukkan bahwa ROA merupakan salah satu ukuran kinerja keuangan yang seringkali dijadikan dasar perhitungan seorang investor dalam investasi. Dengan melihat nilai ROA maka seorang investor akan dapat mengetahui apakah kinerja perbankan tersebut baik atau tidak. Kondisi ini akan menguatkan persepsi masyarakat untuk menyimpan dananya di bank, dan secara teoritis masyarakat mempercayai kinerja bank, karena masyarakat menyerahkan uangnya untuk dikelola oleh bank yang berdampak pada peningkatan dana pihak ketiga. Hal ini senada dengan penelitian Susanti (2015) bahwa tingkat keuntungan berpengaruh positif dan signifikan terhadap Dana Pihak Ketiga Perbankan Syariah di Indonesia. Artinya apabila Tingkat Keuntungan perbankan syariah naik maka 


\section{Jurnal Keuangan dan Perbankan | PERBANKAN}

Vol. 20, No.3, September 2016: 487- 495

jumlah dana pihak ketiga perbankan syariah juga akan ikut naik.

LDR berpengaruh signifikan terhadap dana pihak ketiga, yang berarti bahwa semakin tinggi Loan to Deposit Ratio (LDR), maka laba bank semakin meningkat (dengan asumsi bank tersebut mampu menyalurkan kreditnya dengan efektif), dengan meningkatnya laba bank, maka kinerja bank juga meningkat. Besar-kecilnya rasio Loan to Deposit Ratio (LDR) suatu bank akan mempengaruhi kinerja bank tersebut, sehingga penghimpun dana dari masyarakat dapat dikatakan relatif lebih mudah jika dibandingkan dengan dana lainnya, keuntungan dari dana yang berasal dari masyarakat adalah jumlahnya tidak terbatas. Sebagian besar modal yang dimiliki oleh bank adalah bersumber dari dana masyarakat ini (dana pihak ketiga). Sebagai salah satu fungsinya bank melakukan kegiatan penghimpunan dana dari masyarakat atau pihak yang kelebihan dana (surplus unit). Dalam melakukan kegiatan usahanya sehari-hari, bank harus mempunyai dana agar dapat memberikan kredit kepada masyarakat. Salah satunya adalah dana masyarakat yang merupakan mayoritas dari seluruh dana yang dihimpun oleh bank dalam kegiatan usaha sehari-hari (Kuncoro dan Suhardjono, 2011:68). Dana pihak ketiga merupakan sumber dana masyarakat yang dihimpun bank yang terdiri dari giro, tabungan dan deposito.

\section{KESIMPULAN}

Berdasarkan hasil analisis menunjukkan bahwa Kinerja Perbankan yang terdiri dari CAR, BOPO, ROA dan LDR secara simultan berpengaruh signifikan terhadap Dana Pihak Ketiga. Kinerja Perbankan yang terdiri dari CAR, BOPO, ROA dan LDR secara parsial berpengaruh signifikan terhadap Dana Pihak Ketiga. ROA berpengaruh dominan terhadap Dana Pihak Ketiga. Hal ini menunjukkan bahwa ROA lebih dipertimbangkan nasabah dalam menginvestasikan dananya di Bank Persero.

\section{SARAN}

Bagi pihak bank, agar lebih dapat mengumpulkan dana pihak ketiga dengan pengkajian lebih lanjut mengenai optimalisasi sumber-sumber dana pihak ketiga tersebut, dengan meningkatkan kepercayaan masyarakat terhadap kinerja, kapabilitas, integritas dan kredibilitas perbankan. Menjamin keamanan dana nasabah, pelayanan dan pengelolaan serta ekspetasi perkiraan pendapatan yang diperoleh dari penyimpanan dana tersebut. Bank harus mampu mempertahankan predikat sebagai bank sehat karena bank telah menjadi perusahaan go publik dan untuk lebih meningkatkan kepercayaan masyarakat terhadap bank yang bersangkutan.

Bagi masyarakat, diharapkan hasil penelitian ini berguna bagi para calon nasabah dalam mengetahui kinerja perbankan yang berkaitan dengan perannya sebagai lembaga intermediasi serta dapat dijadikan sebagai bahan pengambilan keputusan para calon nasabah dalam memilih bank mana yang akan dijadikan sebagai tempat menyimpan uangnya dengan aman.

\section{DAFTAR PUSTAKA}

Dendawijaya, Lukman. 2009. Manajemen Perbankan. Ghalia Indonesia. Jakarta.

Jumingan. 2011. Analisis Laporan Keuangan. Bumi Aksara. Jakarta.

Kasmir. 2012. Analisis Laporan Keuangan. Rajawali Pers. Jakarta.

Kuncoro, Mudrajad dan Suhardjono. 2011. Manajemen Perbankan Teori dan Aplikasi. BPFE Yogyakarta.

Lukitasari, Yunia Putri dan Andi Kartika. 2015. Analisis Pengaruh Dana Pihak Ketiga, BOPO, CAR, LDR dan NPL Terhadap Kinerja Keuangan Padasektor Perbankanyang Terdaftar Di Bursa Efek Indonesia. INFOKAM. Nomor I / Th. XI/ Maret: 28-39.

Mulyono, Teguh Pudjo. 2007. Manajemen Perkreditan Bagi Rakyat Komersil, BPFE. Yogyakarta. 


\section{Analisis Pengaruh Kinerja Perbankan terhadap Dana Pihak Ketiga Bank Persero \\ Iqbal Firdausi}

Rose, Peter S. 2002. Commercial Bank Management. Fifth Edition. McGraw-HillIrwin.

Simamora, Henry 2006. Akuntansi Basis Pengambilan Keputusan. Salemba Empat. Jakarta.

Sunyoto, Y dan Sam'ani, 2014. Pengaruh Capital Adequacy Ratio, Net Interest Margin dan Return on Asset Terhadap Harga Saham pada Perbankan di BEI Periode 2009 - 2012. Jurnal Ekonomi Manajemen dan Akuntansi. No. 36 / Th. XXI / April: 1-19.
Suyatno, Thomas. 2007. Kelembagaan Perbankan. PT. Gramedia Pustaka. Jakarta.

Undang-Undang Nomor 10 tahun 1998 tentang Perubahan atas Undang-Undang Nomor 7 Tahun 1998 tentang Perbankan.

Susanti, Vera. 2015. Pengaruh Equivalent Rate dan Tingkat Keuntungan Terhadap Dana Pihak Ketiga (DPK) Perbankan Syariah di Indonesia. I-Finance. Vol. 1. No. 1: 113-132. 